\title{
PENGARUH PEMBERIAN JUS TOMAT (LYCOPERSICUM COMMUNE) TERHADAP TEKANAN DARAH WANITA POSTMENOPAUSE HIPERTENSIF
}

\author{
Aryati Puji Lestari, Hesti Murwani Rahayuningsih") \\ Program Studi Ilmu Gizi Fakultas Kedokteran Universitas Diponegoro \\ Jl.Dr.Sutomo No.14, Semarang, Telp (024) 8453708, Email : gizifk@undip.ac.id
}

\begin{abstract}
Background: Hypertension is the third leading cause of death in Indonesia reached $6.7 \%$ of the population mortality at all ages. The blood pressure of postmenopausal women tends to increase due to decreased of the protective effect of estrogens and increased of salt sensitivity. Tomato fruit (Lycopersicum commune) contains potassium and lycopene which has the effect of decreasing blood pressure.

Objective: Determine the effect of consuming tomato juice (Lycopersicum commune) to the blood pressure of hypertensive postmenopausal women.

Method: This study is an experiment with a pre-post test control group design. The numbers of study subjects are 34 respondents with systolic blood pressure $\geq 140 \mathrm{mmHg}$ and or diastolic $\geq 90 \mathrm{mmHg}$. The tomato juice of $200 \mathrm{ml}$ consumption once a day for 7 days is made from 150 gram tomato, 5 gram sugar, and 50 ml water.

Result: There is a decrease in systolic blood pressure of $11.76 \pm 7.276 \mathrm{mmHg}$ and diastolic blood pressure of 8.82 $\pm 3.321 \mathrm{mmHg}$ in the treatment group. The tomato juice consumption significantly influences the decrease in systolic blood pressure and diastolic blood pressure.

Conclusion: The tomato juice significantly decreases the systolic and diastolic blood pressures in postmenopausal hypertensive women.
\end{abstract}

Keywords: tomato juice; blood pressure; hypertension

\begin{abstract}
ABSTRAK
Latar belakang: Hipertensi merupakan penyebab kematian nomor 3 di Indonesia, yakni mencapai 6,7\% dari total kematian pada seтиа umur. Tekanan darah wanita postmenopause meningkat karena menurunnya efek protektif esterogen dan meningkatnya ensitifitas garam. Buah tomat (Lycopersicum commune) mengandung kalium dan likopen yang mempunyai efek menurunkan tekanan darah.

Tujuan: untuk mengetahui pengaruh pemberian jus tomat (Lycopersicum commune) terhadap tekanan darah wanita postmenopause hipertensif.

Metode: Jenis penelitian ini adalah eksperimen dengan pre-post test control group design. Jumlah subjek penelitian 34 orang dengan tekanan darah sistolik $\geq 140 \mathrm{mmHg}$ dan atau diastolik $\geq 90 \mathrm{mmHg}$. Jus tomat sebanyak $200 \mathrm{ml}$ sebanyak 1 kali sehari yang diberikan selama 7 hari terbuat dari 150 gram buah tomat, 5 gram gula pasir, dan $50 \mathrm{ml}$ air.

Hasil: Terdapat penurunan tekanan darah sistolik sebesar $11.76 \pm 7.276 \mathrm{mmHg}$ dan tekanan darah diastolik sebesar $8.82 \pm 3.321 \mathrm{mmHg}$ pada kelompok perlakuan. Pemberian jus tomat berpengaruh secara bermakna terhadap penurunan tekanan darah sistolik dan tekanan darah diastolik setelah dikontrol dengan asupan lemak dan serat.

Simpulan: Pemberian jus tomat secara signifikan dapat menurunkan tekanan darah sistolik dan diastolik pada wanita postmenopause hipertensif.
\end{abstract}

Kata kunci: jus tomat; tekanan darah; hipertensi

\section{PENDAHULUAN}

Hipertensi merupakan penyebab kematian nomor 3 di Indonesia setelah stroke dan tuberkulosis, yakni mencapai $6,7 \%$ dari total kematian pada semua umur. ${ }^{1}$ Hasil Riset Kesehatan Dasar (Riskesdas) yang dilakukan oleh Badan Penelitian dan Pengembangan Kesehatan (Balitbangkes) tahun 2007 menunjukan prevalensi hipertensi secara nasional mencapai 31,7\%. Prevalensi hipertensi di Jawa Tengah pada penduduk berusia $\geq 18$ tahun sebesar $34,9 \%$, sedangkan di Kota Semarang sebesar 40,8\%. ${ }^{2}$

Kejadian hipertensi pada wanita postmenopause cenderung menyamai bahkan lebih tinggi dari pria karena efek protektif hormon esterogen yang menurun. Wanita postmenopause menderita hipertensi lebih dari dua kali dibandingkan dengan wanita premenopause. Selain efek protektif hormon esterogen, sensitifitas garam 
pada tekanan darah meningkatkan risiko terjadinya hipertensi dan penyakit kardiovaskuler. ${ }^{3}$

Hipertensi berkaitan dengan gaya hidup masyarakat seperti stres, kurang beraktivitas, merokok, konsumsi alkohol yang berlebih, makanan tinggi kadar lemak, asupan natrium yang tinggi, kurangnya asupan kalium dan serat. ${ }^{4}$ Tomat merupakan bahan makanan tinggi asam folat, vitamin C, dan kalium. ${ }^{12}$ Kandungan kalium dalam 100 gram tomat adalah $245 \mathrm{mg} .{ }^{5}$ Kalium dapat menurunkan tekanan darah dengan mengurangi natrium dalam urine dan air dengan cara yang sama seperti diuretik. Hasil penelitian tahun 2004 pada pasien hipertensi rawat jalan di Bandung menunjukkan penurunan tekanan sistolik 10,28 $\mathrm{mmHg}$ dan diastolik $3,49 \mathrm{mmHg}$ dengan melakukan intervensi menggunakan jus tomat yang terbuat dari 150 gram buah tomat dan 5 gram gula pasir dengan lama intervensi 2 hari berturut-turut. ${ }^{6}$

Tujuan dari penelitian ini adalah untuk mengetahui sejauh mana pengaruh pemberian jus tomat terhadap penurunan tekanan darah sistolik dan diastolik pada penderita hipertensi. Hasil dari penelitian ini diharapkan dapat memberikan informasi tentang kandungan dalam tomat yang dapat berpengaruh terhadap penurunan tekanan darah sistolik dan diastolik pada penderita hipertensi serta dapat dijadikan rujukan tambahan untuk penelitian berikutnya.

\section{METODE}

\section{Karakteristik subjek dan sampel}

Penelitian dilakukan di Panti Werda Pengayoman dan Panti Wredha Harapan Ibu Semarang pada bulan Oktober-November 2010. Ruang lingkup penelitian ini adalah penelitian gizi masyarakat. Desain penelitian adalah eksperimen dengan rancangan pre-post test control group design. Subjek penelitian diambil dari seluruh anggota populasi terjangkau, yaitu wanita postmenopause di Panti Werda Pengayoman dan Panti Wredha Harapan Ibu Semarang yang mempunyai tekanan darah sistolik $\geq 140 \mathrm{mmHg}$ dan atau diastolik $\geq 90 \mathrm{mmHg}$.

Besar sampel penelitian ini adalah 34 orang, dengan kelompok perlakuan dan kelompok kontrol masing-masing 17 orang. Kriteria inklusi adalah mempunyai tekanan darah sistolik $\geq 140$ $\mathrm{mmHg}$ dan atau diastolik $\geq 90 \mathrm{mmHg}$, usia $\geq 55$ tahun, tidak teratur mengkonsumsi obat antihipertensi, tidak mengkonsumsi alkohol, tidak mempunyai penyakit penyerta seperti penyakit gangguan ginjal, bersedia mengikuti penelitian dan dapat diajak berkomunikasi. Subjek penelitian ini diambil dengan cara purposive sampling.

Variabel bebas dalam penelitian ini adalah konsumsi jus tomat yang diukur dalam satuan mililiter ( $\mathrm{ml})$, variabel terikat adalah tekanan darah sistolik dan diastolik $(\mathrm{mmHg})$, variabel perancu adalah umur, indeks masa tubuh (IMT), kebiasaan olah raga, merokok, minum kopi, asupan lemak (g), serat (mg), natrium (mg), kalium (mg), kalsium (mg) dan magnesium (mg) yang diukur dengan metode food recall selama 2 × 24 jam. Metode food recall digunakan karena pelaksanaannya mudah, murah, cepat, dapat digunakan untuk subjek yang buta huruf, dan dapat memberikan gambaran nyata asupan individu. ${ }^{7}$

Data yang dikumpulkan adalah data tekanan darah sistolik dan diastolik subjek sebelum dan sesudah intervensi, berat badan, tinggi badan, identitas subjek, riwayat hipertensi dalam keluarga, kebiasaan olah raga, merokok, konsumsi kopi, asupan lemak, serat, natrium, kalium, kalsium, serta magnesium dari makanan selain intervensi.

Pengukuran tekanan darah sistolik dan diastolik diperoleh dengan menggunakan Sphygmomanometer air raksa oleh perawat sebanyak dua kali pengukuran dengan selang waktu \pm 3 menit kemudian direrata. Pengukuran tekanan darah dilakukan dalam posisi duduk bersandar, setelah beristirahat selama 5 menit dengan kaki menyentuh lantai dan tangan sejajar dengan jantung. Pengukuran pertama dilakukan sebelum intervensi pada pukul 8.00 pagi dan pengukuran kedua dilakukan 1 jam setelah intervensi sebagai evaluasi.

Berat badan ditimbang menggunakan timbangan injak digital dengan ketelitian $0,1 \mathrm{~kg}$. Tinggi badan diperoleh dari estimasi pengukuran tinggi lutut. Data identitas subjek dan faktor risiko hipertensi diperoleh dari kuesioner, meliputi riwayat hipertensi dalam keluarga, kebiasaan merokok, kebiasaan konsumsi kopi, alkohol, dan kebiasaan olah raga. Data asupan lemak, serat, natrium, kalium, kalsium, dan magnesium diperoleh melalui metode food recall 24 jam yang dilakukan sebanyak 2 kali.

Pemberian jus tomat (Lycopersicum commune) pada kelompok perlakuan sebanyak 200 $\mathrm{ml}$ terbuat dari $150 \mathrm{~g}$ tomat, $5 \mathrm{~g}$ gula pasir dan 50 $\mathrm{ml}$ air dibuat dengan cara diblender dan diberikan 1 kali sehari selama 7 hari berturut-turut, sedangkan pada kelompok kontrol tidak diberikan intervensi. Kepatuhan mengkonsumsi jus tomat dilakukan dengan observasi secara langsung kepada subjek. 
Analisis univariat untuk mengetahui deskriptif data dan untuk menguji kenormalan data menggunakan Shapiro-Wilk karena jumlah subjek $<50$. Analisis bivariat untuk mengetahui perbedaan tekanan darah antara sebelum dan setelah intervensi menggunakan Paired t-test pada data yang berdistribusi normal, yaitu perubahan tekanan darah sistolik kelompok kontrol. Wilcoxon digunakan pada data yang tidak berdistribusi normal, yaitu perbedaan tekanan darah antara sebelum dan setelah intervensi tekanan darah sistolik dan diastolik kelompok perlakuan serta perbedaan tekanan darah antara sebelum dan setelah intervensi tekanan darah diastolik kelompok kontrol. Independent t-test digunakan untuk mengetahui perbedaan asupan antara kelompok perlakuan dan kontrol pada data yang berdistribusi normal, meliputi asupan lemak, serat, dan kalium. Mann-whitney digunakan untuk mengetahui perbedaan antar kelompok perlakuan dan kontrol pada data yang tidak berdistribusi normal, yaitu perubahan tekanan darah sistolik dan diastolik, asupan natrium, asupan kalsium, dan asupan magnesium. Analisis multivariat dilakukan untuk mengetahui pengaruh pemberian jus tomat terhadap penurunan tekanan darah dengan mempertimbangkan variabel asupan lemak dan serat. Analisis multivariat ini menggunakan uji statistik anacova. ${ }^{8}$

\section{HASIL PENELITIAN \\ Karakteristik subjek penelitian}

Tabel 1. Distribusi frekuensi beberapa karakteristik subjek penelitian.

\begin{tabular}{lcccccc}
\hline \multirow{2}{*}{ Karakteristik subjek } & \multicolumn{2}{c}{$\begin{array}{c}\text { Perlakuan } \\
(\mathbf{n = 1 7})\end{array}$} & \multicolumn{2}{c}{ Kontrol (n=17) } & \multicolumn{2}{c}{ Total } \\
\cline { 2 - 7 } & $\mathbf{N}$ & $\mathbf{\%}$ & $\mathbf{N}$ & $\mathbf{\%}$ & $\mathbf{N}$ & $\mathbf{\%}$ \\
\hline Kelompok umur & & & & & & \\
$\quad$ 55-74 tahun & 5 & 29.4 & 5 & 29.4 & 10 & 29.4 \\
$\quad$ 75 tahun & 12 & 70.6 & 12 & 70.6 & 24 & 70.6 \\
IMT & & & & & & \\
$\quad$ Underweight & 6 & 35.3 & 8 & 47.1 & 14 & 41.2 \\
$\quad$ Normal & 6 & 35.3 & 6 & 35.3 & 12 & 35.3 \\
$\quad$ Overweight & 3 & 17.6 & 2 & 11.8 & 5 & 14.7 \\
$\quad$ Obese 1 & 2 & 11.8 & 1 & 5.9 & 3 & 8.8 \\
Riwayat hipertensi & & & & & & \\
$\quad$ Tidak tahu & 7 & 41.2 & 10 & 58.8 & 17 & 50.0 \\
$\quad$ Ada & 5 & 29.4 & 3 & 17.6 & 8 & 23.5 \\
$\quad$ Tidak ada & 5 & 29.4 & 4 & 23.5 & 9 & 26.5 \\
Kebiasaan olah raga & & & & & & \\
$\quad$ Teratur & 3 & 17.6 & 1 & 5.9 & 4 & 11.8 \\
$\quad$ Tidak teratur & 14 & 82.4 & 16 & 94.1 & 30 & 88.2 \\
Kebiasaan merokok & & & & & & \\
$\quad$ Merokok & 0 & 0 & 0 & 0 & 0 & 0 \\
$\quad$ Tidak merokok & 17 & 100 & 17 & 100 & 34 & 100 \\
Kebiasaan minum kopi & & & & & & \\
$\quad$ Minum kopi & 1 & 5.9 & 5 & 29.4 & 6 & 17.6 \\
$\quad$ Tidak minum kopi & 16 & 94.1 & 12 & 70.6 & 28 & 82.4 \\
\hline
\end{tabular}

Sebagian besar subjek berumur $>75$ tahun, status gizi kurang, tidak teratur berolah raga, tidak mempunyai kebiasaan minum kopi. Seluruh subjek tidak memiliki kebiasaan merokok. Karakteristik subjek penelitian secara keseluruhan dapat di lihat pada Tabel 1.

Asupan lemak, serat, natrium, kalium, kalsium, dan magnesium selama penelitian

Tabel 2. Distribusi frekuensi asupan subjek selama penelitian.

\begin{tabular}{lllcccc}
\hline & \multirow{2}{*}{ Asupan } & & \multicolumn{2}{c}{ Perlakuan } & \multicolumn{2}{c}{ Kontrol } \\
\cline { 3 - 6 } & & $\mathbf{n = 3 4}$ & \% & $\mathbf{n = 3 4}$ & \% \\
\hline $\begin{array}{c}\text { Lemak } \\
\text { Normal }\end{array}$ & $(\leq 30 \%$ & kebutuhan & 6 & 35.3 & 4 & 23.5
\end{tabular}




\begin{tabular}{|c|c|c|c|c|c|}
\hline \multicolumn{6}{|l|}{ energi) } \\
\hline $\begin{array}{l}\text { Tinggi } \\
\text { energi) }\end{array}$ & kebutuhan & 11 & 64.7 & 13 & 76.5 \\
\hline \multicolumn{6}{|l|}{ Serat } \\
\hline Kurang (<20 mg/hari) & & 1 & 5.9 & 16 & 94.1 \\
\hline Normal ( $\geq 20 \mathrm{mg} / \mathrm{hari})$ & & 16 & 94.1 & 1 & 5.9 \\
\hline \multicolumn{6}{|l|}{ Natrium } \\
\hline Normal $(\leq 2300 \mathrm{mg})$ & & 4 & 23.5 & 6 & 35.3 \\
\hline Tinggi $(\geq 2300 \mathrm{mg})$ & & 13 & 76.5 & 11 & 64.7 \\
\hline \multicolumn{6}{|l|}{ Kalium } \\
\hline Kurang $(<3500 \mathrm{mg})$ & & 12 & 70.6 & 16 & 94.1 \\
\hline Normal $(\geq 3500 \mathrm{mg})$ & & 5 & 29.4 & 1 & 5.9 \\
\hline \multicolumn{6}{|l|}{ Kalsium } \\
\hline Kurang (< 800 mg) & & 4 & 23.5 & 16 & 94.1 \\
\hline Normal ( $\geq 800 \mathrm{mg}$ ) & & 13 & 76.5 & 1 & 5.9 \\
\hline \multicolumn{6}{|l|}{ Magnesium } \\
\hline Kurang (<280 mg) & & 6 & 35.3 & 7 & 41.2 \\
\hline Normal ( $\geq 280 \mathrm{mg})$ & & 11 & 64.7 & 10 & 58.8 \\
\hline
\end{tabular}

Asupan lemak dan natrium subjek secara kategori normal. Asupan makanan subjek keseluruhan termasuk dalam kategori tinggi. penelitian secara keseluruhan dapat di lihat pada Asupan serat, kalium dan kalsium sebagian subjek Tabel 2.

termasuk dalam kategori kurang. Asupan Perbedaan tekanan darah sistolik dan diastolik magnesium sebagian besar subjek termasuk dalam sebelum dan sesudah intervensi

Tabel 3. Perbedaan tekanan darah sistolik sebelum dan sesudah intervensi

\begin{tabular}{lllccccc}
\hline & \multicolumn{2}{c}{ TDS sebelum } & \multicolumn{2}{c}{ TDS sesudah } & \multicolumn{2}{c}{$\Delta$ TDS } & \multirow{2}{*}{$\mathrm{p}$} \\
\cline { 2 - 7 } & Rerata & SD & Rerata & SD & Rerata & SD & \\
\hline Perlakuan (n=17) & 139.41 & 8.269 & 127.65 & 5.623 & 11.76 & 7.276 & $0.001^{\mathrm{a}}$ \\
Kontrol (n=17) & 152.06 & 18.630 & 149.41 & 20.531 & 7.21 & 14.099 & $0.546^{\mathrm{b}}$ \\
& & & & & $P=0.085^{\mathrm{c}}$ & \\
\hline
\end{tabular}

TDS $=$ tekanan darah sistolik, $\Delta$ TDS $=$ penurunan tekanan darah sistolik, $\mathrm{a}=$ Uji Wilcoxon, $\alpha=0.05 ; \mathrm{b}=$ Uji Paired T-test, $\alpha=0.05 ; \mathrm{c}=$ Uji Mann-Whitney, $\alpha=0.05$

Tabel 3 menunjukkan pada kelompok penurunan tekanan darah sistolik $(\mathrm{p}>0.05)$. Secara perlakuan terjadi penurunan tekanan darah sistolik keseluruhan penurunan tekanan darah sistolik pada secara signifikan $(\mathrm{p}<0.05)$ sebesar $11.76 \mathrm{mmHg}, \quad$ kedua kelompok tidak signifikan $(\mathrm{p}>0.05)$. sedangkan pada kelompok kontrol tidak terjadi

Tabel 4. Perbedaan tekanan darah diastolik sebelum dan sesudah intervensi

\begin{tabular}{lccccccc}
\hline & \multicolumn{2}{c}{ TDD sebelum } & \multicolumn{2}{c}{ TDD sesudah } & \multicolumn{2}{c}{$\Delta$ TDD } & \multirow{2}{*}{$\mathrm{p}$} \\
\cline { 2 - 7 } & Rerata & \multicolumn{1}{c}{ SD } & Rerata & SD & Rerata & SD & \\
\hline Perlakuan $(\mathrm{n}=17)$ & 91.76 & 3.930 & 82.94 & 4.697 & 8.82 & 3.321 & $0.000^{\mathrm{a}}$ \\
Kontrol (n=17) & 95.00 & 10.607 & 98.24 & 12.493 & 2.79 & 10.459 & $0.282^{\mathrm{a}}$ \\
& & & \multicolumn{4}{c}{$P=0.000^{\mathrm{b}}$} \\
\hline
\end{tabular}

$\mathrm{TDD}=$ tekanan darah diastolik, $\Delta \mathrm{TDD}=$ penurunan tekanan darah diastolik, $\mathrm{a}=$ Uji Wilcoxon, $\alpha=0.05 ; \mathrm{b}=$ Uji Mann-Whitney, $\alpha=0.05$

Tabel 4 menunjukkan pada kelompok perlakuan terjadi penurunan tekanan darah diastolik secara signifikan $(\mathrm{p}<0.05)$ sebesar 8.82 $\mathrm{mmHg}$, sedangkan pada kelompok kontrol tidak terjadi penurunan tekanan darah diastolik ( $\mathrm{p}>0.05)$. Secara keseluruhan terdapat perbedaan penurunan tekanan darah diastolik pada kedua kelompok $(\mathrm{p}<0.05)$. 


\section{Pengaruh jus tomat terhadap tekanan darah sistolik dan diastolik setelah dikontrol dengan}

variabel asupan lemak, serat, dan kalium

Tabel 5. Pengaruh pemberian jus tomat terhadap tekanan darah sistolik dan diastolik dengan variabel kontrol asupan lemak, serat dan kalium.

\begin{tabular}{|c|c|c|c|c|c|}
\hline \multirow[t]{2}{*}{ Variabel } & \multicolumn{2}{|c|}{ Perlakuan } & \multicolumn{2}{|c|}{ Kontrol } & \multirow[t]{2}{*}{$\mathrm{p}^{*}$} \\
\hline & Rerata & SD & Rerata & SD & \\
\hline$\Delta \mathrm{TDS}$ & 11.76 & 7.726 & 7.21 & 14.099 & 0.014 \\
\hline \multicolumn{6}{|l|}{ Kovariat } \\
\hline Asupan lemak & 47.577 & 2.528 & 53.724 & 9.262 & 0.008 \\
\hline Serat & 18.338 & 1.196 & 13.518 & 3.528 & 0.180 \\
\hline Kalium & 3359.241 & 346.573 & 2157.147 & 715.073 & 0.324 \\
\hline$\Delta \mathrm{TDD}$ & 8.82 & 3.321 & 2.79 & 10.459 & 0.019 \\
\hline \multicolumn{6}{|l|}{ Kovariat } \\
\hline Asupan lemak & 47.577 & 2.528 & 53.724 & 9.262 & 0.046 \\
\hline Serat & 18.338 & 1.196 & 13.518 & 3.528 & 0.665 \\
\hline Kalium & 3359.241 & 346.573 & 2157.147 & 715.073 & 0.683 \\
\hline
\end{tabular}

Rerata penurunan tekanan darah sistolik dan diastolik setelah dikontrol dengan asupan lemak, serat, dan kalium didapatkan nilai yang bermakna $(\mathrm{p}<0.05)$ baik terhadap tekanan darah sistolik maupun diastolik. Hasil analisis anacova selengkapnya dapat dilihat pada Tabel 5.

\section{PEMBAHASAN}

Hasil penelitian menunjukkan pada kelompok perlakuan terjadi perubahan tekanan darah sistolik dengan rata-rata penurunan sebesar $11.76 \pm 7.276 \mathrm{mmHg}$ dan tekanan darah diastolik dengan rata-rata penurunan sebesar $8.82 \pm 3.321$ mmHg. Pada kelompok kontrol tidak terdapat penurunan pada tekanan darah sistolik dan tekanan darah diastolik. Pengaruh pemberian jus tomat setelah dikontrol dengan asupan lemak, serat, dan kalium menunjukkan penurunan yang signifikan terhadap tekanan darah sistolik maupun diastolik.

Asupan lemak pada penelitian ini berpengaruh secara signifikan terhadap penurunan tekanan darah sistolik dan tekanan darah diastolik. Asupan asam lemak jenuh dapat meningkatkan plasma kolesterol LDL, mengurangi asupan asam lemak jenuh dan meningkatkan asupan asam lemak tak jenuh dapat menurunkan tekanan darah serta risiko penyakit jantung. ${ }^{9}$ Pada kelompok perlakuan terjadi penurunan tekanan darah walaupun 16 orang $(94.1 \%)$ mengkonsumsi lemak dengan kategori tinggi dan memiliki rasio asam lemak jenuh dengan asam lemak tak jenuh lebih dari 1 .
Hal tersebut disebabkan karena kelompok perlakuan mendapat penambahan serat dari jus tomat sebesar 14 gram yang dapat memberikan efek penurunan tekanan darah. ${ }^{10}$ Mekanisme serat dalam menurunkan tekanan darah, berhubungan dengan asam empedu. Serat pangan mengurangi kadar kolesterol yang bersirkulasi dalam plasma darah, karena serat pangan dapat mengikat garam empedu, mencegah absorbsi kolesterol dalam usus, dan rneningkatkan ekskresi asam empedu ke feses, sehingga meningkatkan konversi kolesterol plasma menjadi asam empedu. ${ }^{11,12}$ Serat membutuhkan waktu paling sedikit 8 minggu untuk menurunkan tekanan darah secara maksimal. ${ }^{13}$

Sebanyak 16 orang $(94.1 \%)$ pada kelompok kontrol dan 12 orang $(70.6 \%)$ pada kelompok perlakuan mengkonsumsi kalium dengan kategori kurang. Diet rendah kalium dapat menyebabkan terjadinya hipertensi. ${ }^{11}$ Kalium berfungsi sebagai natriuretik, yaitu menyebabkan peningkatan pengeluaran natrium dan cairan. ${ }^{14}$

Kalium dalam jus tomat menurunkan tekanan darah sistolik dan diastolik dengan menghambat pelepasan renin sehingga terjadi peningkatan ekskresi natrium dan air. Renin beredar dalam darah dan bekerja dengan mengkatalisis penguraian angiotensin menjadi angiotensin I. Angiotensin I berubah menjadi bentuk aktifnya yaitu angiotensin II dengan bantuan Angiotensin Converting Enzyme (ACE). Angiotensin II berpotensi besar meningkatkan 
tekanan darah karena bersifat sebagai vasoconstrictor dan dapat merangsang pengeluaran aldosteron. Aldosteron meningkatkan tekanan darah dengan jalan retensi natrium. Retensi natrium dan air menjadi berkurang dengan adanya kalium, sehingga terjadinya penurunan volume plasma, curah jantung, tekanan perifer, dan tekanan darah. ${ }^{15}$

Zat selain kalium dan serat yang mungkin berperan dalam penurunan tekanan darah adalah likopen yang dalam penelitian ini belum diteliti. Hasil penelitian pemberian $250 \mathrm{mg}$ ekstrak likopen terhadap 30 penderita hipertensi tingkat I selama 8 minggu menunjukkan likopen mampu menurunkan tekanan darah sistolik sebesar $9 \mathrm{mmHg}$ dan tekanan darah diastolik sebesar $7 \mathrm{mmHg}$ serta memberikan pengaruh yang baik terhadap lipid darah, lipoprotein, dan oxidative stress markers. ${ }^{16}$

Aktifitas antiaterosklerosis likopen terjadi secara oksidatif dan non oksidatif. Pada mekanisme oksidatif, likopen mencegah aterosklerosis dengan memproteksi biomolekul seluler penting, seperti lipid dan lipoprotein. Dalam mekanisme non oksidatif, efek antiaterosklerosis likopen bekerja sebagai agen hipokolesterolemik dengan menghambat laju HMG-CoA (3-hydroxy-3- methylglutaryl-coenzim A) reduktase yang berperan penting pada sintesis kolesterol, serta mengaktifkan reseptor LDL. ${ }^{17}$

Hasil penelitian menunjukkan 11 orang (64.7\%) pada kelompok kontrol dan 13 orang (76.5\%) pada kelompok perlakuan mengkonsumsi natrium dengan kategori tinggi, tetapi tidak ada pengaruh yang bermakna secara statistik antara konsumsi natrium dengan perubahan tekanan darah. Natrium yang berlebihan di dalam tubuh secara tidak langsung meningkatkan volume cairan ekstrasel, yang akan meningkatkan volume darah, sehingga meningkatkan tekanan pengisian sirkulasi rata-rata, meningkatkan aliran balik darah vena ke jantung, meningkatkan curah jantung, dan meningkatkan tekanan arteri. ${ }^{18}$

Asupan kalsium 16 orang $(94.1 \%)$ pada kelompok kontrol dan 14 orang $(82.4 \%)$ pada kelompok perlakuan termasuk kategori kurang, sedangkan asupan magnesium 11 orang $(64,7 \%)$ pada kelompok kontrol dan 10 orang $(58.8 \%)$ pada kelompok perlakuan termasuk kategori normal. Hasil analisis diketahui bahwa baik konsumsi kalsium maupun magnesium tidak berpengaruh secara signifikan terhadap tekanan darah. Asupan kalsium dan magnesium yang tinggi dapat menurunkan tekanan darah. ${ }^{3,11,18}$
Kalsium memiliki efek natriuretik, dan berpengaruh dalam menurunkan tekanan darah pada pasien hipertensi sensitif $\mathrm{NaCl}$. Bila asupan $\mathrm{NaCl}$ berlebih meningkatkan eksresi kalsium urine, kadar hormon paratiroid, dan konsentrasi 1,25 dihydroxivitamin D. Hormon paratiroid menyebabkan vasokonstriksi dengan cara mempengaruhi aktivitas neural dan atau hormon vasoaktif. ${ }^{17}$ Magnesium merupakan inhibitor dari kontraksi otot polos pembuluh darah dan berperan dalam pengaturan tekanan darah sebagai vasolidator. Kekurangan magnesium menyebabkan penyempitan dinding arteri dan kapiler dan berpengaruh terhadap kejadian hipertensi. ${ }^{3,11}$

\section{SIMPULAN}

Pemberian $200 \mathrm{ml}$ jus tomat (Lycopersicum commune) sebanyak satu kali dalam sehari selama 7 hari berpengaruh terhadap penurunan tekanan darah sistolik sebesar 11.76 $\mathrm{mmHg}(8,4 \%)$ dan tekanan darah diastolik sebesar $8.82 \mathrm{mmHg}(9.6 \%)$ pada wanita postmenopasue hipertensif.

\section{SARAN}

1. Perlu sosialisasi mengenai manfaat buah tomat sebagai upaya untuk mencegah dan mengatasi tekanan darah tinggi.

2. Perlu penggunaan instrument lain seperti food frequency questionaire sebagai pelengkap metode food recall untuk mengetahui asupan subjek.

\section{DAFTAR PUSTAKA}

1. Hipertensi penyebab kematian nomor tiga.[editorial]; 2010. Available from: URL: HYPERLINK: http://www.dinkesjatengprov.go.id

2. Riset kesehatan dasar (riskesdas) 2007. Jakarta: Departemen Kesehatan Republik Indonesia. 2008

3. Debra AK. Medical Nutrition in Hypertension. In: Mahan K,Escott-Stump S editors. Krause's food, nutrition and diet therapy. $11^{\text {th }}$ edition. Philadelphia: Saunders; 2004. p. 900-918.

4. Forman JP, Stamfer MJ, Curban GC. Diet lifestyle risk factors associated with incident hypertension in women. JAMA [serial online] 2009 [dikutip pada 5 April 2010]; 302(4);401-11. Available from: URL: HYPERLINK: http://jama.amaassan.org

5. Almatsier S. Prinsip Dasar Ilmu Gizi. Jakarta: Gramedia Pustaka; 2002. hal.221-233.

6. Gunawan IZ, praminanto G, rahayu DY. Pengaruh pemberian jus belimbing dan tomat terhadap perubahan tekanan darah sistolik dan diastolik pada penderita hipertensi di Puskesmas Taragog dan RS Al Islam Bandung dalam Prosiding 
Perteuan Ilmiah National Dietetik II. Jawa barat. Bandung: Asosiasi Dietisien Indonesia; 2005. hal.405-11.

7. Supariasa I, Bakri B, Fajar I. Penilaian status gizi. Jakarta: Penerbit Buku Kedokteran EGC. hal. 9496.

8. Riyanto S. Pengolahan dan analisis data kesehatan. Yogyakarta: Nuha Medika; 2009. hal.61-121.

9. Ramussen BM, et al. Effects of dietary saturated, monosaturated, and n-3 fatty acids on blood pressure in healthy subjects. American Journal Clinical Nutrition [serial online] 2006 [dikutip pada 14 Juli 2011]; 83: 221-6. Avaible from: URL: HYPERLINK: http://www.ajcn.org

10. Bazzano LA. Dietary intake of fruit and vegetable and risk of diabetes mellitus and cardiovascular disease. USA: World Health Organization (WHO); 2005.

11. Rolfes SR, Pinna K, Whitney E. Understanding normal and clinical nutrition. 7th edition. USA: Peter Marshall; 2002. Rolfes SR, Pinna K, Whitney E. Understanding normal and clinical nutrition. 7th edition. USA: Peter Marshall; 2002.

12. Muchtadi D. Sayuran sebagai sumber serat pangan untuk mencegah timbulnya penyakit degeneratif. Jurnal teknol dan pangan 2001 XII (1): hal.62-71.

13. Whelton SP, Hyre AD, Pedersen B, Yi Y, Whelton PK, He J. Effect of dietary fiber intake on blood pressure: a meta-analysis of randomized, controlled clinical trials. Journal of Hypertension [serial online] 2005 [dikutip pada 13 September 2012]; 23(3): 245-81. Avaible from: URL: HYPERLINK: http://www.lww.org

14. Meneton P. Potassium and it's role in reducing arterial blood pressure. [serial online] 2006 [dikutip pada 11 Maret 2010]. Available from: URL: HYPERLINK: http://www.ifava.org

15. Murray RK, Bender DA, Botham KM, Kennelly PJ, Rodwell VW, Weil PA. Harper's Illustrated Biochemistry. $28^{\text {th }}$ edition. USA: McGraw-Hill Companies. 2009.

16. Paran E, Engelhard Y. Effect of tomato's lycopene on blood pressure, serum lipoproteins, plasma homocysteine and oxidative stress markers in grade I hypertensive patients. Am J Hypertens [serial online] 2001 [dikutip pada 13 Desember 2011]; 141A. Abstract. Available from: URL: HYPERLINK: http://www.amjh.org

17. Agarwal S, Rao AV. Role of antioxidant lycopene in cancer and heart disease. J Am Coll Nutr; [serial online] 2000 [dikutip pada 1 April 2010]; 19(5):563-9. Available from: URL: HYPERLINK: http://www.jacn.org

18. A Theodore, Kotchen JM. Nutrition, Diet, and Hypertension. Dalam: Shils ME. Modern Nutrition In Health and Disease tenth edition. Philadelphia: Lippincott Williams and Wilkins; 2006. hal. 10951102. 